\title{
Decoupling of kimberlite source and primitive melt compositions
}

\author{
MADELINE TOVEY ${ }^{1 *}$, ANDREA GIULIANI ${ }^{12}$, DAVID \\ PHILLIPS $^{1}$, CHIRANJEEB SARKAR ${ }^{3}$, D. GRAHAM \\ PEARSON $^{3}$, TOM NOWICKI ${ }^{4}$ AND JON CARLSON ${ }^{5}$ \\ ${ }^{1}$ School of Earth Sciences, University of Melbourne \\ (*correspondence: toveym@student.unimelb.edu.au) \\ ${ }^{2}$ Institute for Geochemistry and Petrology, ETH Zurich \\ ${ }^{3}$ Earth and Atmospheric Sciences, University of Alberta \\ ${ }^{4}$ Mineral Services Canada, Vancouver \\ ${ }^{5}$ Dominion Diamond Corp., Calgary
}

Kimberlites emplaced since $\sim 2 \mathrm{Ga}$ show $\mathrm{Nd}$ and $\mathrm{Hf}$ isotopic compositions that follow a remarkably consistent linear evolution [1]. However, kimberlites emplaced $<200 \mathrm{Ma}$ within a few thousand kilometers of the western paleo-margin of Pangea (i.e. Brazil, southern Africa, and Lac de Gras in western Canada) deviate towards more enriched $\mathrm{Nd}$ and $\mathrm{Hf}$ isotopic compositions possibly due to contribution by recycled crustal material, introduced to the deep kimberlite source via subduction [1].

To address this anomaly further we have compared new and existing geochronological and $\mathrm{Nd}$ isotopic data for 28 kimberlites from Lac de Gras (LDG; ca. 47 - $75 \mathrm{Ma}$ ) with their olivine and spinel mineral chemistries. Olivine grains typically include mantle-derived xenocrystic cores $(\mathrm{Mg} \#=$ 83.5-94.2) overgrown by magmatic rims with relatively constant Mg\# values. Olivine rims and chromite are the first magmatic phases to crystallise from kimberlite and can be used as proxies for primitive melt compositions. The average $\mathrm{Mg} \#$ of olivine cores from each kimberlite is positively

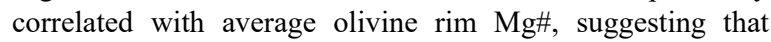
assimilation of heterogeneous lithospheric mantle contributed to the primitive melt compositions.

The $\varepsilon \mathrm{Nd}_{(\mathrm{i})}$ values from whole-rock and perovskite from LDG kimberlites vary between -3.4 and -0.4 that are negatively correlated with their emplacement ages. This correlation is indicative of an evolving kimberlite source which may have resulted from a progressively lower contribution of recycled material. No systematic relationships were observed between olivine rim or chromite compositions and age or $\mathrm{Nd}$ isotopic composition. This observation highlights decoupling between kimberlite source evolution and primitive melt compositions due to the combined effects of crustal recycling in the kimberlite source and lithospheric mantle assimilation during kimberlite ascent.

[1] Woodhead et al. (2019) Nature 573, 578-581 